Kravchuk H. V.,

Professor, Doctor of Sciences (Economics), Professor of the Department of Economics and Social Sciences, Academy of the State Penitentiary Service, Chernihiv, Ukraine

\title{
CRIMINAL RESPONSIBILITY AND PROBLEMS OF DETENTION OF SHEEP IN MOTOR INSURANCE
}

The article is devoted to issues of detection of abuse in the field of motor insurance in the insurance market of Ukraine. The general tendencies of increasing the volume of motor insurance, increasing the cost of vehicles and increasing prices for repairs of motor vehicles after their participation in road accidents leads to the use of illegal schemes by insurers, insurance agents or insurers to obtain material benefits. Not the regulation of this issue in the articles of the Criminal Code leads to ambiguity in relation to this type of fraud in insurance.

Taking into account mentioned above and guided by the Criminal Code, the insurer, in case of revealing "preliminary conspiracy" or "abuse of trust", must transfer the case to the court with the possibility of bringing the perpetrators to administrative or criminal liability.

As a result of this study, the impossibility of identifying the most interested side in the implementation of insurance fraud should be pointed out. That is why it is expedient to introduce an article, dedicated to insurance fraud, into the Criminal Code of Ukraine. It is worth distincting of liability for fraudsters and fraudsters-insurers through the definition of general social damage from such actions.

Key words: European minutes, fraud, insurance, damage, automobile.

Target setting. The current state of the insurance market of Ukraine is characterized by a steady tendency to increase the volume of motor insurance, which includes KASKO, OSTSPV and "Green Card". According to the statistics, there is an increase in traffic accidents involving both material (property) and non-material (caused by life and health) damage, which entails insurer's obligation to fulfill duty in accordance with the terms of the contract. Economic problems of the population lead to unwillingness to spend money on concluding contracts in order to reduce the level of risk, and in case of an accident, they try to solve the problem through illegal actions. In general, a significant number of destructive factors affecting the insurance market leads to more active insurance fraud. Therefore, the main thing in investigating fraud as a type of insurance crime is to study the motives of its commission, to analyze the factors of influence on this kind of crime in the insurance market and also possible means of avoiding insurance fraud. 
Taking into account social and economic importance of the insurance industry, offences in insurance sphere, which recently increase, threaten not only insurers' financial stability and insolvency, but also the reduction of insurers' confidence in insurance coverage, the deterioration of the quality of insurance services, which, as a result has negative impact on the development of the insurance market. Insurance fraud interferes with the fulfillment of its main functions and the formation of transparent relations between insurers and policyholders, which led to the writing of this scientific article.

Actual scientific researches and issues analysis. Problems of functioning of the insurance market and motor transport insurance, in particular, are devoted to the work of such leading scientists as O. O. Hamankova, S. S. Osadets, O. V. Kozmenko. Attention at the issue of insurance fraud was paid in scientific researches of A. Alhazin, L. Andrushchenko, S. Balina, H. Borzenkov, N. Hutorova, V. Lytvynenko, O. Salaichuk, D. Tyschenko and many other domestic and foreign scientists.

Insurance fraud is becoming an increasingly problematic aspect of the functioning of insurance market, the provision of insurance services, the formation of relationships between insurers, insurers and insurance agents, but significant or universal developments in minimizing the risk of fraud have not yet been implemented. Therefore, the question of the need for a study to systematize approaches to detect possible fraudulent activities in the field of insurance and prevention arises.

The purpose of the article is to identify sources of insurance fraud and drawbacks in the definition of criminal liability for fraud in the field of insurance.

The statement of basic materials. For understanding the relevance of current study, it is necessary to provide data on trends in the development of such a segment of insurance market as motor transport insurance. According to the National Financial Services Commission, for the period of the 1st half of 2016-2017 there was an increase in the volume of insurance premiums for motor insurance from 4142.6 million UAH to 4626.0 million UAH, that is an increase of 483.4 million UAH or $11.7 \%$ per specified period. At the same time there is a disproportionate increase in the amount of insurance 
payments from UAH 1721.0 million to UAH 2,289.8 million, which indicates an increase in absolute amount of UAH 568.7 million, and a relative increase of $33.0 \%$. Such tendencies are determined by the undoubtedly economic factors that increase the cost of repair and restoration work for motor vehicles and negative dynamics of the increase in the number of accidents. In the absence of separate static information on the implementation of unlawful actions in order to receive insurances or overestimate the cost of repair and restoration work, it can be only assumed that such disproportionate increase in payments for payments also led to insurants or insurers' fraudulent actions. Also, changes in the structure of insurance payments and payments may indicate abuse in this area of insurance, in particular, the structure of insurance payments in the insurance of individuals is $22.0 \%$ of the civil liability insurance of land vehicle owners 1534.0 million UAH, which is 103.7 million UAH (or $7.3 \%$ ) more than in the first half of 2016, insurance of ground transportation (CASCO) received UAH 1328.1 million, or $19.0 \%$, which is UAH 204.3 million (or by $18.2 \%$ ) more compared to 2016 . The bulk of insurance payments $(31.7 \%)$ was made under civil liability insurance contracts of land vehicle owners (OSTSPV) - UAH 757.3 million, which is by UAH 221.9 million (or $41.4 \%$ ) more compared from 2016; part of the insurance payments $(28.0 \%)$, made under the insurance contracts of land transport (CASCO), is 667.6 million USD, which is 144.1 million USD (or $27.5 \%$ ) more compared with 2016.

The level of loss-making under land transportation insurance contracts (CASCO), concluded with individuals, amounted to $50.3 \%$, under the civil liability insurance contract of land vehicle owners (OSTSPV) - 49.4\%. To determine the general trends in the development of the market for motor insurance, we give the data in Table in terms of changes in key indicators by type of insurance for the first half of 2016-2017 years.

Thus, according to Table, there is an increase in gross insurance premiums from auto insurance (CASCO, OSTSPV, Green Card) in the first half of 2017 by $13.5 \%$, and gross insurance premiums by $32.7 \%$. During the first half of 2017, gross insurance premiums for land transport insurance (CASCO) increased by $23.3 \%$ compared to the same period in 2016 and amounted to UAH 2,593.7 million dur- 
ing civil liability insurance for land vehicle owners (OSTSPV), gross insurance premiums grew by $6.1 \%$ and amounted to UAH 1836.9 million. The volume of gross insurance premiums during the insurance of CASCO for the first half of 2017 amounted to UAH 1230.0 million, which is $30.7 \%$ more than for the same period in 2016; the volume of gross insurance premiums during the insurance of OSTSPV amounted to UAH 916.9 million, which is $40.8 \%$ more than in the same period of 2016. Such data indicate negative development of this sector of insurance, which is conditioned by the high level of its loss-making (Table).

Table

Dynamics of key indicators of auto insurance for the first half

of the year 2016-2017

\begin{tabular}{|c|c|c|c|c|c|c|c|c|}
\hline \multirow{3}{*}{$\begin{array}{c} \\
\text { Land transport } \\
\text { insurance } \\
\text { (CASCO) }\end{array}$} & \multirow{2}{*}{\multicolumn{2}{|c|}{$\begin{array}{l}\text { Gross insur- } \\
\text { ance bonuses, } \\
\text { million UAH }\end{array}$}} & \multirow{2}{*}{\multicolumn{2}{|c|}{$\begin{array}{l}\text { Gross insurance } \\
\text { payments, mil- } \\
\text { lion UAH }\end{array}$}} & \multirow{2}{*}{\multicolumn{2}{|c|}{$\begin{array}{l}\text { Level of } \\
\text { gross insur- } \\
\text { ance pay- } \\
\text { ments, } \%\end{array}$}} & \multicolumn{2}{|c|}{ Rate growth, $\%$} \\
\hline & & & & & & & \multirow{2}{*}{$\begin{array}{l}\begin{array}{c}\text { insur- } \\
\text { ance } \\
\text { bonuses }\end{array} \\
23.3\end{array}$} & \multirow{2}{*}{\begin{tabular}{|l|}
$\begin{array}{l}\text { insurance } \\
\text { payments }\end{array}$ \\
30,7 \\
\end{tabular}} \\
\hline & 2103,8 & 2593,7 & 941,0 & 1230,0 & 44,7 & 47,4 & & \\
\hline $\begin{array}{c}\text { Obligatory } \\
\text { insurance of } \\
\text { civil liability of } \\
\text { owners of land } \\
\text { vehicles } \\
\text { (OSTSPV) }\end{array}$ & 1731,2 & 1836,9 & 651,4 & 916,9 & 37,6 & 49,9 & 6,1 & 40,8 \\
\hline $\begin{array}{c}\text { Obligatory } \\
\text { insurance of } \\
\text { civil liability of } \\
\text { owners of land } \\
\text { vehicles } \\
\text { "Green Card" }\end{array}$ & 602,4 & 606,1 & 201,4 & 233,7 & 33,4 & 38,6 & 0,6 & 16,0 \\
\hline Total & 4437,4 & 5036,7 & 1793,8 & 2380,6 & 40,4 & 47,3 & 13,5 & 32,7 \\
\hline
\end{tabular}

In the Criminal Code, only Article 190 defines fraud as "taking ownership of someone else's property or acquiring a property right by deception or abuse of trust", that is, without distinguishing between the sphere of implementation and the subject that has acted. Responsibility for fraudulent activities also does not distinguish the scope of their implementation, but only depends on proving the very fact of fraud in court. Thus, fraudulent actions under the Criminal Code are punishable by a fine of up to fifty non-taxable minimum incomes, or 
correctional labor for a term up to two years, or restraint of liberty for a term up to three years. Fraud committed repeatedly, or by a previous convocation by a group of persons, or which caused significant harm to the victim, shall be punishable by a fine of 50 to 100 tax-free minimum incomes, or correctional labor for a term of one to two years, or restraint of liberty for a term up to five years, or imprisonment for a term up to three years.

Recently, there has been an increase in the number of lawsuits from insurers to defendants in case, insurers for abuse of trust by drawing up false euro protocols based on the results of an accident and benefiting from repair and restoration work. At that time, in the structure of the insurers themselves, there are insurance agents who abuse their official duties for the purpose of obtaining benefits by issuing insurance policies after the commission of an accident or the execution of insurance contracts on an already damaged car without mentioning defects in contracts (relating to CASCO agreements), or appropriation insurance payments. With regard to the last type of fraud, insurance companies must protect their property interests by filing a lawsuit in court in civil or commercial proceedings, or report a criminal offense to law enforcement agencies by filing a civil claim, but most insurers worry about their reputation on the market and not wish to disclose these facts and solve such issues by concluding an oral agreement between the agent who committed the abuse and the insurer's administration, which provides for the loss of damages incurred by the latter.

In order to reduce the risk of corporate fraud at the stage of entering into an insurance contract, it is expedient to observe the following measures: to keep a register of insurance agents in the mode of free access for insured persons; to provide the mode of access of consumers of insurance services to information systems MTSBU, including the register of insurance agents, deprived of the right to engage in intermediary activities in the field; to determine the rating of the quality of work of insurance agents by the scores exhibited by the policyholders on the results of cooperation with them.

The purpose of fraudulent actions when selling insurance policies is to obtain illicit income from insurers in the form of insurance payment through the use of corrupted, invalid or fake forms. The proce- 
dure for internal control of an insurer should consist in ensuring timely receipt of insurance payments for all issued policies on behalf of the insured. The policyholder has to pay for himself or receive a document on payment of the insurance payment together with a copy of the insurance policy, which will be a confirmation of payment of funds for the concluded contract. Such control will reduce the number of cases involving the activities of insurance agents who do not list or recalculate with a significant delay in insurance premiums of the insurer.

It should be noted that even in case of fraud detection, the insurance agent or employee of the company will be released, but only will reimburse the value of the insurance policy and the specified insurance premium, as without court's decision to commit fraud, the insurance company can not use any other material charges. For the insurer, the losses are much higher, because they are deteriorating reputation, loss of insurers, lack of revenues from insurance activities, excessive costs of personnel management by reducing funding for other activities of the insurer. For the insurer, the consequences of fraudulent actions of the insurer's employees are the termination of the contract or failure to pay the insurance indemnity, that is, the loss of confidence in the insurance company from the failure to fulfill its insurance functions.

On the other hand, insurers themselves often use the insurance procedure to generate income, which is an unconditional breach of the insurance policy, according to which the insurance indemnity should not bring the insurer profit. The reliable determination of the amount of insurance indemnity, similarly to efficiency, is an important aspect at the stage of regulation of losses. When the size of the insurance indemnity is higher or lower compared to the other insurance commissioners established before payment of similar insurance claims, there is a probability of biased evaluation. The reason for the non-objective assessment of the insurance loss may be material interest of the employee of the company in over-compensation of the amount of the "abuse of trust" by the insurer's management and the "prior conspiracy" with the insured or the victim. As a result, such actions increase the inadequacy of insurance reserves and worsen the insurer's solvency. 
Another area of insurance fraud is the use of European protocols, which are drawn directly by the participants of the road accident without involving the road inspectorate and the representative of the insurance company (emergency commissioner). This document is the basis for the payment of insurance compensation subject to the following conditions: both the participants of the accident are issued OSATSV policies, there are no bodily injuries to the victims, drivers are not in a state of narcotic or alcoholic intoxication and the amount of damage does not exceed UAH 50 thousand.

Because of the fact, that according to the conditions of European protocols drafting guiltiness of the person is assessed on the basis of an agreement between the participants of the accident, which to some extent is a reason for fraud, that is, when there is an agreement between the parties. Insurers may "by prior agreement" draw up protocols for an accident that was not actually in order to obtain insurance compensation by one or both parties for damages received by another, except for given accident, by way of, at other times and / or in other circumstances. The existence of this document offers great opportunities for insurance fraud.

Proceeding from the above-mentioned and guided by the Criminal Code, the insurer, in the event of a "preliminary conspiracy" or "abuse of trust" should be identified, must transfer the case to the court with the possibility of bringing the perpetrators to administrative or criminal liability.

Conclusions. As a result of maintained research, it should be noted, that there is impossibility of identifying the most interested party in the implementation of insurance fraud. That is why it is expedient to introduce an article in the Criminal Code of Ukraine on insurance fraud, with the distinction of liability for fraudsters and fraudsters-insurers through the definition of general social damage from such actions.

\section{References}

1. Kryminalnyi kodeks Ukrainy [The Criminal Code of Ukraine]. [Elektronnyi resurs]. http://zakon.rada.gov.ua/laws/show/2341-14 (in Ukrainian).

2. Salaichuk O. Shakhraistvo ta protydiia yomu v avtostrakhuvanni [Fraud and counteraction to it in auto insurance] [Elektronnyi resurs] / O. Salaichuk // Rezhym dostupu: http://www.ufin.com.ua/analit_mat/strah_rynok/129.htm (in Ukrainian). 
3. Tyshchenko D. Shakhraistvo na strakhovomu rynku [Fraud in the insurance market] /D. Tyshchenko // Strakhova sprava. - 2012. - № 2 (46). S. 46-47 (in Ukrainian).

Кравчук Г. В.

\section{КРИМІНАЛЬНА ВІДПОВІДАЛЬНІСТЬ ТА ПРОБЛЕМИ ВИЯВЛЕННЯ ШАХРАЙСТВА В АВТОТРАНСПОРТНОМУ СТРАХУВАННI}

Стаття присвячена питанням виявлення зловживання у сфері автотранспортного страхування на страховому ринку України. Загальні тендениії збільшення обсягів моторного страхування, збільшення вартості транспортних засобів та підвищення цін на відновлювально-ремонтні роботи автотранспортних засобів після їх участі в дорожньо-транспортних пригодах приводить до використання нелегальних схем страхувальниками, страховими агентами або страховиками для отримання матеріальної вигоди. Неврегульованість иього питання в статтях Кримінального кодексу приводить до неоднозначного ставлення до такого виду шахрайства в страхуванні.

Ключові слова: європротокол, шахрайство, страхування, збитковість, автотранспорт.

\section{УГОЛОВНАЯ ОТВЕТСТВЕННОСТЬ И ПРОБЛЕМЫ ВЫЯВЛЕНИЯ МОШЕННИЧЕСТВА В АВТОТРАНСПОРТНОМ СТРАХОВАНИИ}

Статья посвящена вопросам выявления злоупотребления в сфере автотранспортного страхования на страховом рынке Украины. Общие тенденции увеличения объемов моторного страхования, увеличение стоимости транспортных средств и повышение цен на восстановительно-ремонтные работы автотранспортных средств после их участия в дорожно-транспортных происшествиях приводит к использованию нелегальных схем страхователями, страховыми агентами или страховщиками для получения материальной выгоды. Неурегулированность данного вопроса в статьях Уголовного кодекса приводит к неоднозначности отношения к такому виду мошенничества в страховании.

Ключевые слова: европротокол, моченничество, страхование, убыточность, автотранспорт. 